\title{
Cooperation Lending Channel to Women Society in East Java, Indonesia
}

\author{
Agus Sumanto, Grisvia Agustin, Lisa Rokhmani, Sri Handayani \\ Economics Faculty, Universitas Negeri Malang
}

\section{Introduction}

When some people join hands to solve some common difficulty, they are said to be working in cooperation. It may be defined as that form of organization in which some people combine for some common economic purpose. Cooperative associations are formed voluntarily. A cooperative society works on some fundamental principles. First, members join it of their own sweet will. Second, all the members are treated as equals. Third, cooperative societies work according to a democratic constitution. Fourth, they are meant to bring members closer to each other. For these reasons, such societies are started in small localities so that all the members of a particular locality may know each other well. Fifth, cooperation broaden economy literacy among common people.

The first thing cooperative societies do to individual members is development of savings culture. It is an age long established fact that nobody can escape poverty without a savings habit. Anybody that spends everything on consumption is just a step away from poverty and its various consequences, no matter how rich the person is today. This is a great challenge for many people, especially for low income people, whose needs are far more than what they earn. Some of them attempt to save, but because the saving is always within their reach, they find it difficult not to spend the money. Yet, everybody needs to save and invest to escape poverty.

But cooperatives make saving relatively easy for its members. Because a member of a cooperative must contribute saving regularly, most times monthly. The contribution is usually deducted from your income automatically, before they even receive it. So, irrespective of they needs, they save compulsory. Also, because the money is not within easy reach, they cannot easily access it to spend. The second thing you benefit from cooperative as an individual is access to loans either in cash or in the form of goods.

Informal workers usually doesn't have fix monthly salary and they don't own salary receipt. So they have difficulty to access lending channel from commercial banks and other financial institution. For low income earners, it is even worse, because they don't have collateral for the loan. Even for those that can meet the conditions for bank loans, the loan may not come promptly as needed. But as a member of a cooperative, they can access loan promptly. Their contributions serve as collateral and fellow contributors are accepted as guarrantors. Also, the interest rate and repayment terms are not crushing as that of the banks. This easy access to loans has helped many people achieve improved welfare. Niswah Qonita cooperative represents Women Cooperative which provide Saving and Loan channel to its member. The members have various educational, occupation and family background. Most its members are merchant and entrepreneurs. But this cooperative faces internal and external constraint. So this research focus on determine external and internal constraint of lending channel in women cooperation Niswah Qonita.

\section{Literature Review}

Entrepreneurship is important in economic development but little significant has been given to the effect of interdependent communities on entrepreneurial development. The concept of entrepreneurship in this study is defined as personal agency belief which is determined by the individual's perception about their ability to take action which leads to desired outcome and capability.Cooperative Thrift and Credit Societies are member-based organizations that help members to address economic problems. They are not banking institutions because of their goal. The ultimate goal is to encourage thrift among the members and to meet credit needs of people who might otherwise fall prey to loan sharks and other predatory lenders.

Cooperative societies are widely spread organization in developing countries, they are known for strong commitment of, as well as participation in the decision making of their members (Haan et al., 2003). These societies mobilize local savings and administer credit to members, thereby encouraging thrift and entrepreneurial activity. When first started, credit unions use relatively unsophisticated administrative practices, so that the costs are very small and most interest income from loans may either be distributed to the members or reinvested in the credit union within a capitalization programme. Consequently, they can be set up in poor communities, where access to means of secure savings and to credit at non-exploitative terms is of greatest importance (UNDESA, 1999).

The main advantages of cooperative form of business are 


\section{Easy formation:}

The formation of cooperative society is very simple as compared to the formation of other form of business organization. Any two adults can come together and join their hand and form a cooperative society.

The procedure of registration of the society is also very simple and easy. No legal formalities are required for the formation of cooperative society.

\section{Democratic management:}

The management or cooperative is rest on the elected members from among themselves by forming a committee. Every member gas equal say in making policies of the society. "The one man, one vote" principle ensures a democratic management.

\section{Open membership:}

The membership of cooperative societies is open to each and every person. Anybody wishing to enjoy the fruits of a cooperative can join it. Nobody is barred from joining societies on the basis of economic position, caste, color or creed.

A person can enrolled as a member any time he/she likes by contributing the minimum capital. He/she can also withdraw the membership when ever he does not like to continue as a member.

\section{Service motto:}

The cooperative societies are formed not for profits but for providing service. The societies try to promote the interests of the members. A feeling of cooperation is created among members.

\section{Economical Operation:}

The operation carried out by the cooperative society is economical due to the elimination of middlemen. The societies purchase goods directly from producers and sell them to the members at cheap at rates. The services of the middlemen are provided by the members at cheaper rate.

\section{Low management costs:}

The management of a cooperative society is in the hands of persons elected by the shareholders. Members take active interests in the working of the society. Thus, the recurring and non-recurring costs are low.

\section{Sharing of surplus:}

The societies sell goods to its members on a nominal profit to cover up administrative costs. The surplus earned by the society is spent on the basis of cooperative Act.

After meeting the expenses, some portion of the surplus spent for welfare of the members, some portion kept as reserve and balance is distributed among the members.

\section{Check on business:}

The cooperative are stared with service motive while all other forms of business are launched with a profit motive. When businessmen try to exploit consumers by increasing prices of their goods, cooperatives supply commodities at reasonable prices.

The cooperatives provide a check on the business of the other forms of enterprises. Other traders will have to reduce their prices when cooperatives are supplying these goods at lower prices. Consumers are not at the mercy of selfish businessmen.

\section{Limited liability:}

The liability of individual members is limited to the extent of shares purchased capital contributed by him. Thus members can enjoy the benefits of limited liability.

This makes them free from the tear of utilization of their private property, in case of financial crunch to the society.

\section{Internal financing:}

It provides ample scope for internal financing by utilizing the balance of the surplus earned in any year for its growth, development and expansion; because the law governing cooperatives lays down that the dividend on a share in any cooperatives shall not exceed $67 \%$ p.a.

\section{Continuous existence:}

It enjoys the benefit of continuous existence, because its life is not affected by the death, insolvency, lunacy, permanent incapacity or conviction of a member.

Therefore, it has stable life and continues to exist for a long period of time.

\section{Satisfy the needs of poor persons:}

The cooperative organizations are best suited to meet the needs of the poorer sections of the India society. These solve their economic problems and improve their economic conditions.

\section{Perfect co-ordination:}

Service before self (which is the guiding spirit of cooperation) as the foundation of a cooperative organization makes them the best possible service organizations for promoting public interest and welfare.

Since the members of a cooperative organization belong to a local area or a particular class or group who are entrusted by the ideals of cooperation, its management actually benefits from a perfect coordination among the members of the Managing Committee. 


\section{Desirable form of business:}

The cooperative organization is desirable forms of business even from the social stand point particularly because it lays more emphasis on the moral character and the development of personal qualities.

It fosters a fellow feeling among its members and imparts those moral and educative values to their everyday life which are essential for a better living.

\section{Reduction of glaring disparity in the National Income:}

Above all, the benefits and profits of a cooperative organization are enjoyed by those people who actually deserve such gains thereby reducing to some extent the glaring disparity.

The advantages of cooperation are numerous. It eliminates the middle man. In this way it helps the farmers in getting credit at a low rate of interest. Moreover, the members work very economically as they know that the gain of the society will be their own gain. Apart from this, cooperation proves morally advantageous. Members have to be very honest and of high character. Dishonest persons, gamblers, drunkards, etc., are not allowed to be the members of a cooperative. So the members try keep themselves morally high. Besides this, cooperation has many educational and social advantages also. Thus, its advantages for a poor and backward country like India cannot be over-emphasized.

In spite of so many advantages, cooperative also faces difficulties. The illiteracy of the members is one of them. They fail to understand its basic principles. They do not take as much interest in the working of the societies as educated members. Not much attention has been paid towards the non-credit cooperative societies. This has left a large number of people out of the scope of cooperation. It cannot be successful without the active and voluntary work of the members. But in our country cooperation is governed by the Government. Besides, no proper and strict check has been kept on the accounts of cooperatives. This and many other drawbacks have been responsible for the slow growth of the movement.

Some suggestions may now be made for the rapid progress of the cooperative movement. In the first place, credit should be advanced only for productive purpose. Strict check should be kept, so that credit facilities are not misused for any other purpose except that for which the credit has been taken. Members should be educated so that they may understand the basic principles of cooperation. Multipurpose cooperatives should replace single purpose societies. This will help in promoting the movement. Keeping in view the vast scope of cooperation and favorable conditions available in our country for it, every effort should be made to make the movement a success. Existing theoretical works on credit cooperatives emphasize three principles of cooperative organization that are of particular significance to their performance:

\section{a. the identity principle (or solidarity principle)}

make this market segment so unattractive for conventional banks, can be drastically reduced by this system of reciprocal or, so to speak, neighbourly monitoring (Stiglitz 1990). However, the advantage of low monitoring costs as a result of the peer monitoring system is offset by the disadvantage of the quantitative and qualitative limitation on the transformation potential of the credit cooperative as a financial institution. Owing to its fixed circle of members, a cooperative has only limited capacity for transformation in terms of amounts, maturity and risk. In order for peer monitoring to work, the group must be homogeneous and restricted to a small, easily manageable number of members, yet at the same time precisely these factors are a constraint on the financial efficiency of the institution (Krahnen/Schmidt 1994). Furthermore, many credit cooperatives were originally set up as self-help groups based on the ideal of solidarity, and in most cases the desire to gain access to cheap credit without having to go through bureaucratic formalities was probably uppermost in the minds of the founders. An inherent structural weakness of these credit-motivated cooperatives is their limited power to generate savings because they (have to) pay lower interest rates on deposits than are obtainable on alternative forms of investment. This weakness should be seen as an indirect cost of the policy of providing low-interest credit.

\section{b. the nominal capital principle (or redeemability principle)}

means that the equity capital of the cooperative members is, in economic terms, really only a shareholder's loan as it can, in principle, be reclaimed at any time and then repayable at nominal value. In practice, the distinction between shareholdings and deposits is also frequently blurred. This situation obliges the credit cooperative to maintain a comparatively high volume of liquid reserves. Retained earnings, on the other hand, are not in danger of being redeemed or withdrawn. As a consequence, the formation of internal reserves (retained earnings) results in an irredeemable and non-voting item of equity capital. It is therefore reasonable to assume that the management of credit cooperatives will be in favour of retaining a relatively large portion of its profits.

\section{c. the equality principle (or democracy principle)}

which implies that voting rights at the general meeting are not proportionate to the volume of capital invested, undermines in principle the motivation, normally inherent in equity capital, to exercise control, and invites a "free rider" mentality. As the number of members, i.e. the size of the credit cooperative, increases, this negative incentive is magnified. This in effect eliminates the regulatory function of relatively large, active 
investors, typical of joint stock companies. The ideal small cooperative has many of the characteristics of an institutionally formalized Rotating Saving and Credit Association (RoSCA). It is founded on peer monitoring; its financial performance is limited, and belonging to a regional or national network (as, for example, in a multitier cooperative system) brings no significant improvement to its level of efficiency. Sustained growth is only achieved under exceptional circumstances - if, for example, a company, through its payroll department, acts on behalf of members as a de facto trustee in overseeing the credit cooperative's operations.

\section{Research Methodology}

The study adopted cross-sectional whereby data were collected at single pont of time.This design were preferred, for despite its simplicity. It allows one to collect data about past and current experiences to identify possible cause and effect association.

\section{Result and Discussion}

Research reveals that there is no non-performing loan at Niswah Qonita co-operation. All the creditors always pay the loan in time. This quiete interesting fact because non-performing loan is common issue in banks and financial institution. Factors which influence loan payment in time are

a. personal characteristics such as age, education background and the family ammount

b. business characteristic such as business value and establishment period

c. credit characteristic consist of base value, credit period, and credit frequency

Procedure for the co-operation member recruitment which strictly due to recital community is so constituted to feel high belief in God and aware of obligation on credit that should be payed on time.The results of the study indicate that members of Niswah Qonita Co-operation in the study area were better entrepreneurs than non-members. This may be as a result of the interdependent nature of these societies and provision of accessible credit. Key characteristics of respondents such as gender and education had a significant effect on their entrepreneurial level. This study discovered that gender (being female) had a negative effect on personal agency belief while education had a positive effect. This is consistent with Van Praag's (2005) argument that the effect of gender is negative while that of education is positive on entrepreneurship. Membership of Niswah Qonita Co-operation also predicts personal agency belief.

Svendsen and Svendsen (2004) argue that positive externality is created through cooperation and Kalantaridis (2004) suggests that group based institutions are good for dealing with uncertainty. All these support the assertion that an interdependent society such as Cooperative Thrift and Credit Societies promotes entrepreneurship apart from the provision of loans. The implication of these results is that the Federal Government of Nigeria may consider developing policies that will create an enabling environment for the development and proper operation of Cooperative Thrift and Credit Societies and other group based initiatives. This is important because societies like this could serve as an important mechanism for the support of entrepreneurs who are alert to opportunities in their environment.

\section{Conclusion}

Informal finance could be developed and managed in such a way that their activities will generate a more desirable outcome. Microentrepreneurs feel comfortable borrowing from the informal sector. Even if the interest rate and collateral of banks is accessible to microentrepreneurs, they may still refuse to borrow from anything called a bank. The name "Bank" may be a disincentive for borrowing, so people should be encouraged to do things their own way while a regulatory framework compatible with the people's value system is in place to check exploitation. In fact Audretsch et al. (2006) argue that banks are not appropriate for financing innovative firms.

\section{References}

[1]. Sameer. 2016. What are The Main Advantages of Cooperative Form Business. http://www .publishyourarticles .net/eng/articles2/ what-are-the-main-advantages-of-cooperative-form-of-business/2765/

[2]. Chaterjee, Milan. 2014. AN Essay on The Cooperative Movement in India. http://www.publishyourarticles.net/knowledgehub/essay/an-essay-on-the-cooperative-movement-in-india/1244/

[3]. Adekunle, Bamidele and Spencer J. Henson. 2007. The effect of cooperative thrift and credit societies on personal agency belief: a study of entrepreneurs in Osun State, Nigeria. African Journal of Agricultural Research Vol. 2 (12), pp. 678-686, December 2007

[4]. Kwai, Melania D. and Justin K. Urassa. 2015. The Contribution of Saving and Credit Cooperative Societies to Income Poverty Reduction: A Case Study of Mbozi District, Tanzania. Jurnal of African Studies Development. Vol 7(4), pp. 99-111, April 2015.

[5]. Llanto, Gilberto M. 1994. The Financial Structure and Performance of Philippine Credit Cooperatives. Philippine Institute for Development Studies. DISCUSSION PAPER SERIES NO. 94-04.

[6]. Krahnen, Jan P. and Reinhard H. Schmidt. 1995. On the theory of credit cooperatives: Equity and onlending in a multi-tier system. Enterprise and Cooperative Development Department. International Labour Office Geneva 